\title{
Work Engagement and Turnover Intention: The Moderating Effect of Organizational Justice
}

\author{
Kiky D. H. Saraswati ${ }^{* *}$ Daniel Lie ${ }^{1}$ \\ ${ }^{1}$ Faculty of Psychology, Universitas Tarumanagara, Jakarta 11440, Indonesia \\ "Corresponding author.Email: kikys@fpsi.untar.ac.id
}

\begin{abstract}
The success of an organisation largely depends on its employees. Employers put forward different ideas to retain employees as to avoid turnover, which can cause both financial and moral loss to employers as well as employees. The actual employees' turnover behavior is strongly predicted by turnover intention and one factor that affects it is work engagement. Many studies have consistently shown that the relationship between work engagement and turnover intention is significantly negative. However, there is an inconsistency pertaining to the strength of its association and there could be a moderating variable affecting the two variables. Therefore, the objective of this study is to test whether organizational justice plays its role as a moderator in the correlation of work engagement and turnover intention. This study used a cross-sectional and quantitative design. Data were analysed from 225 employees in Jakarta, Indonesia, in which they were required to complete a series of questionnaires to measure all three variables. Regression analysis confirms the role of organizational justice (together with its three dimensions) as a moderating variable $(\mathrm{F}=23.26 ; \mathrm{p}<$ 0.05). Hence, it is recommended for the employers to consider employees' perceived organizational justice when they intend to promote work engagement as a way to decrease the employees' turnover intention.
\end{abstract}

Keywords: Work engagement, turnover intention, organisational justice, moderating variable, employee

\section{INTRODUCTION}

The role of employees is inevitable when discussing about organisation effectiveness. Some speculate that employees are the backbone or the greatest assets of every organisation. Employees are required to have related skills, knowledge, and experience so that they can work effectively and efficiently to aid organisation to accomplish its desired objectives and goals. Thus, it is essential for any organisation to retain their employees by proposing different ideas or providing organisational supports to fulfil and satisfy their needs. However, when employees are dissatisfied with their job or any treatments given by the organisation, they tend to leave the organisation for good.

When an employee leaves an organisation is defined as turnover [1]. Turnover is usually interpreted as an unfortunate event for any organisation because its costs are worrying. Since 2010, costs related with turnover are high. It nearly doubled from $\$ 331$ billion to $\$ 617$ billion. At the current trend, it has been projected that it could hit to $\$ 800$ billion by 2023 [2]. Supporting this data, one of data companies in America, PayScale [3], stated that to replace highly skilled employees costs five times than replacing an entry-level employee. Another consequence of turnover is that it disrupts well-being for both employees and employers. Employees who are working in a team can have difficult time bonding with the rest of the members if the members keep leaving or changing. Moreover, it is a draining process for employers to keep training the new hires. Besides, each remaining employee at the organisation will have more workload which may result in demoralization and not to forget it can cause stress or challenge for employers searching a suitable replacement at a short period of time following the turnover [4].

As turnover causes financial as well as moral losses, employers are critically examining different methods to lower down the turnover rates. One of which is through assessing employees' turnover intention [1,5]. Turnover intention is the likelihood that an employee will depart an organisation [6]. It is a choice made by the employee to leave their current employer and can be measured quantitatively [7]. In short, turnover intention acts as an indicator of whether employees are thinking to leave their employment [8]. Turnover intention is one of the strongest predictors of the actual turnover [9] because both variables are highly correlated [5] and turnover intention accounts for $25 \%$ of the actual turnover behaviour [1]. Consistent with this view, Bluedorn [10] cited 23 studies in his literature review and highlighted that there is a positive correlation between turnover intention and actual leaving behaviour. Hence, this explains why many practitioners and researchers have continuously focused and identified key variables in predicting turnover intentions $[11,12]$. 
One of key variables that predicts turnover intentions is work engagement. Engaged employees are energetic and always focus in completing their work. They interpret work as challenging rather than stressful or demanding. Accordingly, work engagement is described to those employees who are having energy, involvement, and efficacy [13], which are exactly the opposite of burnout and that is exhaustion, cynicism, and reduced accomplishment [14]. In other word, the definition of work engagement is characterised as (a) vigor, (b) absorption, and (c) dedication [15, 13]. Moreover, in the following year, Schaufeli [16] further explained that work engagement and employee engagement have different meaning although both are often used simultaneously.

How work engagement correlates with turnover intention is clearly justified from various past literatures. Engaged employees tend to be enthusiastic regarding their work, occupied with high levels of positive energy, causing them to focus in completing their work and hence making them enjoy their work [16]. This enjoyment causes an employee not to think for negative thoughts [17] or display their higher-positive quality behaviour [18]. Example of such behaviour is having an idea not to leave the organisation [9]. In short, work engagement theoretically predicts turnover intention.

Empirically, various research studies have consistently concluded that the association between work engagement and turnover intention is negative. However, what remains debatable is the strength of the correlation between both variables that varies among studies. According to Cohen, Cohen, West, and Aiken [19], the strength of the correlation between any two variables can be measured by an effect size and that is interpreted to have either a small, medium, or a large effect. The rule of thumb is, based on Cohen et al. [19], when coefficient of determination is ranging from 0.01 to 0.09 is described as having a small effect size, 0.091 to 0.25 as having a medium effect size, and lastly 0.0251 to 1 is characterised as having a large strength.

A quantitative research conducted by Gupta and Shaheen [9] yielded a conclusion that the magnitude of the relationship between work engagement and turnover intention is small. They conducted both online and offline survey questionnaire using a sample of 228 Indian employees. Result shows that the association between work engagement and turnover intention is negative. Specifically, work engagement accounts for $9 \%$ of variance in turnover intention. Hence, based on Cohen et al. [19], the strength of the correlation between both variables is considered having a small effect size.

Contrary to the findings from Gupta and Shaheen [9], many studies in the recent years have suggested that the size of the association between work engagement and turnover intention is medium $[20,21,22]$. For instance, $\mathrm{Li}$ et al., [20] performed a cross-sectional mail-survey design research and their participants were 410 Chinese nurses. Result indicates that correlation between work engagement and turnover intention is significantly negative. Besides, work engagement also explains for $14.44 \%$ of variance in turnover intention. Based on Cohen et al.'s [19] reference, the strength of both variables is classified having a medium effect size. Similarly with the Li et al.'s [20] conclusion, Agarwal and Gupta [22] also specified that the strength of how work engagement associates with turnover intention is medium. They adopted a survey questionnaire method to collect the data from 1,302 Indian managers. The result stipulates that work engagement is correlated negatively with turnover intention in which work engagement accounts for $16 \%$ of variance in turnover intention.

Opposed to the literature findings collected in India [9, 22] and China [20], multiple research studies have claimed that the size of the relationship among work engagement and turnover intention is having larger effect size [23, 24, 25, 26]. For example, Merissa [24] carried out a nonexperimental research and data were collected from 120 employees working at one of the shopping malls in Indonesia. Result reveals work engagement affects turnover intention negatively and accounts for $28.25 \%$ of variance in turnover intention. On the other hand, in Hermawan et al.'s [23] study, they recruited employees who were working at Bali Airport in Indonesia as their participants and used questionnaires to collect the data. Accordingly, they reported that work engagement is negatively correlated with turnover intention and that work engagement explains for $82.63 \%$ of variance in turnover intention. Although both studies concluded identical conclusion of having larger effect size, one should notice that there is a large difference in term of the magnitude of its strength, in which it may lead to some doubts pertaining to the correlation between both variables.

The literature findings above can be summed up to one main idea that how work engagement associates with turnover intention in the negative direction is proven empirically. However, what remains inconsistent is the strength of the correlation between the two variables. With this notion, one may deduce that there could be a third variable that occurs in between the correlation of work engagement and turnover intention. Based on Baron and Kenny's [27] study, this third variable is in fact named as moderating or moderator variable. Furthermore, Namazi dan Namazi [28] also mentioned that moderator variable could affect the amount of the correlation of the dependent and independent variable. With that, one might say that there should be a moderating variable in between the correlation of work engagement and turnover intention, resulting its strength to be inconsistent among research studies.

One possible moderating variable that may enhance the correlation of those two variables is organisational justice. Organisational justice refers to the perception on how organisational resources are distributed fairly [29]. The term fairness is coined as justice which means decisions and actions taken by management [30]. Organisational justice consists of three dimensions and they are (a) distributive justice, (b) procedural justice, and (c) interactional justice.

The definition of distributive justice is perceived fairness related to the distribution of resources within an organisation [31]. This type of justice refers to the 
allocation of monetary or non-monetary resources such as giving monthly salary or praise after helping other employees to complete a task.

Procedural justice is defined as how organisational policies and procedures lead to any decision outcomes [31]. It takes on the process in which how organisation reaches to a decision. This involves procedural issues such as how an employee is (a) recruited and selected, (b) getting a reward or punishment. In short, procedural justice is achieved when employees perceive that managerial process and procedures are perceived to be fair [30].

Interactional justice means that the fairness on how an employee is being treated by other people or how an employee evaluates fairness via social or communication criteria. This includes (a) interpersonal justice and (b) informational justice [31, 32]. The first aspect focuses on perception of how an individual is being respected in any circumstance. For example, are employees being treated with respect and dignity? On the other hand, the informational justice focuses on the perception of whether management provides sufficient information and explanation to the employees. For instance, is management is willing to share important information? [30].

Theoretically, the idea of having organisational justice as a moderator in the relationship between work engagement and turnover intention could be supported. It could be justified by social exchange theory. Social exchange theory simply means that when one party receives a favourable treatment from the other party, the receiver obligates him/her to provide favourable treatment in return $[33,34]$. In this case, organisational justice being the moderator alters the magnitude of the linkage between the two variables. This means that if employees perceive themselves of being treated fairly by the organisation to a large extend, they are obligated to do something in return to the organisation by focusing in completing the work and eventually they will stay and do not have any idea of leaving the organisation. Contrary, when employees perceived that they are being treated less fairly by the organisation, employee will not give their best effort in focusing or completing the works. Besides, they are not occupied with high level of energy but giving them more space and time in thinking negative thought or displaying their behaviour and one of which is having an idea of leaving the organisation.

Not only theoretically, the proposal of having organisational justice as a moderating variable in the relationship of work engagement and turnover intention is also supported empirically under three notions and they are: (a) the effect of organisational justice to work engagement is positive, (b) organisational justice effects negatively with turnover intention, and (c) organisational justice has been proven to be a moderator in a correlation between independent and dependent variables.

First, many studies have repeatedly concluded that organisational justice affects work engagement positively [35, 36, 37]. Cao et al. [36], as an example, conducted a descriptive cross-sectional research design for two months and recruited 569 newly licensed registered nurses working in the hospital across Beijing as their participants. Structural equation modelling analysis shows that the relationship between organisational justice and work engagement is positive. Furthermore, Navarro-Abal et al. [37] also has identical finding as Cao et al. [36] and their result was based on a study conducted in Spain using 543 university students and they were tasked to complete a series of questionnaires.

Second, multiple recent literatures have consistently shown that organisational justice has a negative effect on turnover intention $[38,39,40,41]$. For example, Mengstie's [40] study followed a mixed research method in which it involved 197 healthcare workers. They used self-report questionnaire and semi-structured interview to analyse the data. Regression analysis implies that organisational justice negatively accounts for $9.9 \%$ variation in turnover intention. Supporting Mengstie's [40] result, Ekmekcioglu and Aydogan [39] reported a similar finding (organisational justice affects turnover intention significantly in negative direction) in which their data were based on 339 employees working in one of the Turkey financial institutions who completed questionnaires that had been translated to Turkish language.

Third, past literature studies have shown that organisational justice successfully moderates some correlation between predictor and criterion [42, 43, 44, 45, 46]. For instance, Kwantes and Bond [43] hypothesised that organisational justice moderates the correlation between social and organisational cynicism in their Canadian and American participants. Hierarchical regression analysis supported their hypothesis. Furthermore, recently, Wei et al. [46] conducted a survey study to examine whether organisational justice could successfully moderate the correlation between psychological empowerment on voice behaviour. They recruited a total of 236 Chinese employees. Result clearly confirms the role of organisational justice as a moderating variable.

Based on social exchange theory and literature findings supporting the three notions, one could infer that the relationship of work engagement and turnover intention is most likely to be moderated by organisational justice. Organisational justice may alter the magnitude of both variables, resulting its effect size to be different among studies found in the current literature. However, no research study has been found examining these three variables concurrently. Therefore, the aim of this current study is to investigate whether organisational justice able to moderate the association of work engagement and turnover intention.

Proposed hypothesis in this study are as follows:

$\mathrm{H}_{1} \quad$ : work engagement contributes significantly towards turnover intention

$\mathrm{H}_{2} \quad$ : organisational justice significantly moderates work engagement's correlation with turnover intention

$\mathrm{H}_{3} \quad$ : the dimensions of organisational justice significantly moderate work engagement's correlation with turnover intention 
The model of the current study is described in the Figure 1 below:

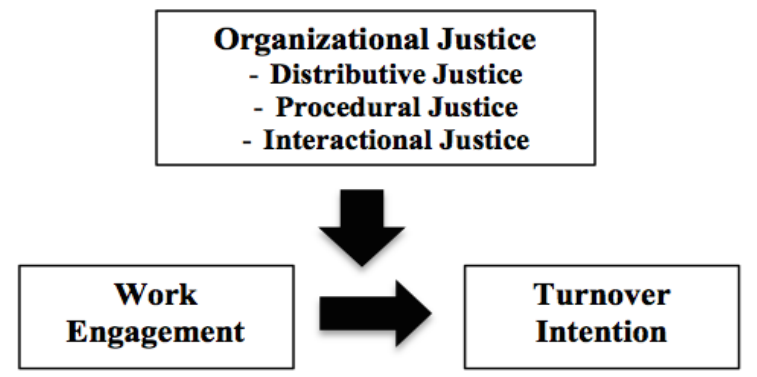

Figure 1 Research model

\section{RESEARCH METHODOLOGY}

This study used a non-experimental and quantitative method and data were analysed based on the response of 225 participants. The participants were permanent employees of a manufacture company located in Jakarta, Indonesia. Information of the demographics of the participants are depicted in the Table 1.

Table 1 Demographic characteristics of the participants

\begin{tabular}{|l|l|c|}
\hline Gender & Male & $91.56 \%$ \\
& Female & $8.44 \%$ \\
\hline Age & $21-25$ & $15.11 \%$ \\
& $26-30$ & $40.89 \%$ \\
& $31-35$ & $36.44 \%$ \\
& $36-40$ & $7.56 \%$ \\
\hline Education & Elementary & $62.22 \%$ \\
& Diploma & $13.33 \%$ \\
& Under and/or Graduate & $24.45 \%$ \\
\hline Position & Team Member & $46.22 \%$ \\
Level & Team Leader & $16 \%$ \\
& Foreman & $19.11 \%$ \\
& Supervisor & $17.33 \%$ \\
& Manager & $1.34 \%$ \\
\hline Years of & $1-5$ & $21.78 \%$ \\
Service & $6-10$ & $30.67 \%$ \\
& $11-15$ & $41.33 \%$ \\
& $>15$ & $6.22 \%$ \\
\hline
\end{tabular}

This study used three questionnaires such as 3-item Utrecht Work Engagement Scale (UWES) (example: "Ketika bekerja, saya merasa asyik dan larut di dalam pekerjaan itu"), 10-item Turnover Intention Scale (example: "Secara aktif, saya mencari perusahaan lain sebagai alternatif tempat bekerja"), and 18-item Organisational Justice Scale (example: "Kesempatan saya untuk memberikan informasi yang akurat dalam proses pengambilan keputusan"). For a better comprehension, the questionnaires had been translated into Bahasa Indonesia. Thus, the participants were enabled to deliver actual response of their perception and attitude towards their work. Each questionnaire uses a five-point Likert-scale (1 $=$ Strongly disagree to $5=$ Strongly agree) .
A reliability analysis was conducted in this study. The result of its analysis is shown in Table 2. It shows that the questionnaires are suitable for measuring the variables:

Table 2 Alpha Cronbach

\begin{tabular}{|c|c|}
\hline Scale & Alpha Cronbach \\
\hline Utrecht Work Engagement Scale & 0.775 \\
\hline Turnover Intention Scale & 0.831 \\
\hline Organisational Justice Scale & 0.933 \\
\hline
\end{tabular}

Regression analysis was conducted with the SPSS Program version 21.

\section{RESULTS}

The results of data analysis that used to investigate the hypothesis are described below.

Hypothesis 1: Work engagement contributes a significant impact towards turnover intention.

Work engagement significantly affects turnover intention $(\mathrm{p}<0.05)$. The analysis result is described in Table 3 .

Table 3 Linear regression analysis of work engagement and turnover intention

\begin{tabular}{|c|c|c|c|c|c|}
\hline & $\begin{array}{c}\text { Sum of } \\
\text { Squares }\end{array}$ & df & $\begin{array}{c}\text { Mean } \\
\text { Square }\end{array}$ & F & Sig. \\
\hline Regression & 322.614 & 1 & 322.614 & 9.626 & .002 \\
\hline Residual & 7474.168 & 223 & 33.516 & & \\
\hline Total & 7796.782 & 224 & & & \\
\hline
\end{tabular}

Table 4 indicates that work engagement contributes $4.1 \%$ impact towards turnover intention. The result of the analysis is as follows:

Table 4 Contribution of work engagement towards turnover intention

\begin{tabular}{|c|c|c|c|}
\hline $\mathbf{R}$ & R Square & $\begin{array}{c}\text { Adjusted } \\
\text { R Square }\end{array}$ & $\begin{array}{c}\text { Std. Error of } \\
\text { the Estimate }\end{array}$ \\
\hline $.203^{\mathrm{a}}$ & .041 & .037 & 5.78934 \\
\hline
\end{tabular}

Hypothesis 2: Organisational justice significantly moderates the correlation of work engagement and turnover intention.

Table 5 exhibits the regression analysis of how organisational justice significantly moderates the correlation of work engagement and turnover intention ( $p$ $<0.05)$.

Table 5 Linear regression analysis of organisational justice as moderator of the correlation of work engagement and turnover intention

\begin{tabular}{|c|c|c|c|c|c|}
\hline & $\begin{array}{r}\text { Sum of } \\
\text { Squares }\end{array}$ & df & $\begin{array}{c}\text { Mean } \\
\text { Square }\end{array}$ & F & Sig. \\
\hline Regression & 1350.71 & 2 & 675.356 & 23.26 & .000 \\
\hline Residual & 6446.07 & 222 & 29.036 & & \\
\hline Total & 7796.78 & 224 & & & \\
\hline
\end{tabular}


Further analysis suggests that organisational justice contributed $17.3 \%$ impact towards work engagement and TI. The result of the analysis is shown in Table 6.

Table 6 Contribution of organisational justice as moderator of the correlation of work engagement and turnover intention

\begin{tabular}{|c|c|c|c|}
\hline $\mathbf{R}$ & R Square & $\begin{array}{c}\text { Adjusted } \\
\text { R Square }\end{array}$ & $\begin{array}{c}\text { Std. Error of the } \\
\text { Estimate }\end{array}$ \\
\hline $.416^{\mathrm{a}}$ & .173 & .166 & 5.38854 \\
\hline
\end{tabular}

Hypothesis 3: The dimensions of organisational justice significantly moderate the correlation of work engagement and turnover intention

Below is the regression analysis of how distributive justice (DJ), procedural justice (PJ), and interactional justice (IJ) significantly moderates the correlation of work engagement and turnover intention $(\mathrm{p}<0.05)$.

Table 7 Linear regression analysis of the dimensions of organisational justice as moderators of the correlation of work engagement and turnover intention

\begin{tabular}{|c|c|c|c|c|c|}
\hline & $\begin{array}{l}\text { Sum of } \\
\text { Squares }\end{array}$ & df & $\begin{array}{l}\text { Mean } \\
\text { Square }\end{array}$ & F & Sig. \\
\hline $\begin{array}{c}\text { Regression } \\
\text { DJ }\end{array}$ & 1412.470 & 2 & 706.235 & 24.558 & .000 \\
PJ & 1084.391 & 2 & 542.195 & 17.932 & .000 \\
IJ & 778.285 & 2 & 389.143 & 12.309 & .000 \\
\hline Residual & & & & & \\
DJ & 6384.312 & 222 & 28.758 & & \\
PJ & 6712.392 & 222 & 30.236 & & \\
IJ & 7018.497 & 222 & 31.615 & & \\
\hline Total & & & & & \\
DJ & 7796.782 & 224 & & & \\
PJ & 7796.782 & 224 & & & \\
IJ & 7796.782 & 224 & & & \\
\hline
\end{tabular}

The contribution of each of the dimensions of organisational justice is explained in the Table 8 .

Table 8 Contribution of the dimensions of organisational justice as moderators of the correlation of work engagement and turnover intention

\begin{tabular}{|c|c|c|c|c|}
\hline Dimension & $\mathbf{R}$ & R Square & $\begin{array}{c}\text { Adjusted } \\
\text { R Square }\end{array}$ & $\begin{array}{c}\text { Std. Error } \\
\text { of the } \\
\text { Estimate }\end{array}$ \\
\hline DJ & .426 & .181 & .174 & 5.36266 \\
\hline PJ & .373 & .139 & .131 & 5.49873 \\
\hline IJ & .316 & .100 & .092 & 5.62271 \\
\hline
\end{tabular}

\section{DISCUSSION}

The result shows that work engagement affects turnover intention significantly $(3.7 \%)$. As supported by many previous studies $[9,20,21,22,23,24,25,26]$, the intention to quit the job decreases as the employees experience a positive attitude towards their work. On the other hand, their intention to leave their employer will likely develop when the employees are occupied with negative attitudes such as burnout, which is also known as the antipode of work engagement [14]. The employees who are highly engaged will also less likely to quit their job because they are fully attached with their organisations [47].

Organisational justice is also found to be a significant moderator toward work engagement and turnover intention $(17.3 \%)$. Previous research results also claimed that organisational justice affects the employee's behaviors and when it fails to implement organisational justice, that may lead to negative behaviour [35]. The role of organisational justice as a moderator can be explained by Job DemandsResources Model [48]. In this case, organisational justice is viewed as an essential source of organisational safety that may enhance the job resources. The employees perceive fairness if they experience justice in distributed rewards, cconsistent and predictable decision making and how their bosses and co-workers treat them. Another perspective to understand how organisational justice affects the relationship of two variables is by applying the social exchange theory in the context [33]. The relationship between the employers and the employees is built on reciprocal exchange. When the employees perceive justice displayed by the employers, they will exchange it by remaining with the organisation.

Further findings suggest that each of the dimensions of organisational justice also contributes significant moderating impacts. Distributive justice is the main contributor $(18.1 \%)$ on work engagement-turnover intention correlation. This finding strengthens the phenomenon which social exchange theory explains, that when the employer provides a fair reward for any efforts the employee has performed, the employee will give the same level of contribution to the employer in return.

The second dimension, procedural justice, ranks as the next significant contributor $(13,9 \%)$. When the employee perceive that fair procedures and policies are implemented in day-to-day management process. According to Job Demands-Resources Model, management process can be classified as a form of resource that the organisation provides for their employees to enable them to achieve their work goals. Moreover, this resource is a significant factor that promotes the employee's work engagement.

Interactional justice also contributes a significant impact towards the two variables $(10 \%)$. Again, this finding can be explained by social exchange theory, in which interpersonal relationship, sufficient information, and explanation to the employees are perceived beneficial. When the employees feel that the organisation treats them respectfully and shares information as if they are an important part of the organisation, they will treat the organisation the same way in exchange.

For further studies, it is recommended for researchers to investigate another demographic aspect, such as employment status. This recommendation is addressed due to the current research which focuses on permanent employees only. An interesting issue may arise among 
temporary employees in the assumption of the different perception of organisational justice from the permanent ones.

The outcome of this study is highly applicable and it delivers significant contribution to industrial and organisational settings. To expect high work performance, employer should create a condusive work atmosphere by providing organisational justice. When their environment is perceived as psychologically safe, the employees will be more engaged emotionally, cognitively, as well as physically. Furthermore, they will reluctantly leave the organisation.

\section{CONCLUSION}

The objective of this study is to explore how organisational justice moderates the relationship of work engagement and turnover intention. This study concludes that organisational justice significantly affects the relationship between work engagement and turnover intention. It proves that the participants perceive that organisational justice provided by the organisation is an essential element that influences their decision to depart the organisation.

\section{ACKNOWLEDGMENT}

This work is supported by Universitas Tarumanagara, Jakarta, Indonesia, especially the Faculty of Psychology.

\section{REFERENCES}

[1] Cho, Y. J., \& Lewis, G. B. (2012). Turnover intention and turnover behaviour: Implications for retaining federal employees. Review of Public Personnel Administration, 32(1), 4 - 23.

[2] Work Institute. (2019). Retention report 2019. Franklin, TN: Work Institute

[3] PayScale. (2019, September 13). Why is employee retention important? Five reasons explained. Retrieved from https://www.payscale.com/compensation-today/ 2019/09/why-is-employee-retention-important

[4] Palesciuc, I. (2019, July 16). Consequences of employee turnover on organizational performance. Retrieved from https://www.performancemagazine.org/ consequences-employee-turnover/

[5] Fernet, C., Trepanier, S. G., Demers, M., \& Austin, S. (2017). Motivational pathways of occupational and organizational turnover intention among newly registered nurses in Canada. Nursing Outlook, 65(4), 444-454.

[6] Mobley, W. H., Horner, S. O., \& Hollingsworth, A. T. (1978). An evaluation of precursors of hospital employee turnover. Journal of Applied Psychology, 63(4). 408-414

[7] Wong, Y., Wong, Y., \& Wong, C. (2015). An integrative model of turnover intention: Antecedents and their effects on employee performance in Chinese joint ventures. Journal of Chinese Human Resources Management, 6(1), 71-90.

[8] Perreira, T. A., Berta, W., \& Herbert, M. (2018). The employee retention triad in health care: Exploring relationships amongst organisational justice, affective commitment and turnover intention. Journal of Clinical Nursing, 27, 1451-1461.

[9] Gupta, M., \& Shaheen, M. (2017). Impact of work engagement on turnover intention: Moderation by psychological capital in India. Business: Theory and Practice, 18, 136-143.

[10] Bluedorn, A. C. (1982). A unified model of turnover from organizations. Human Relations, 35(2), $135-153$

[11] Skelton, A., Nattress, D., \& Dwyer, R. J. (2020). Predicting manufacturing employee turnover intentions. Journal of Economics, Finance, and Administrative Science, 25(49), 101-117.

[12] Ugural, M. N., Giritli, H., \& Urbanski, M. (2020). Determinants of the turnover intention of construction professionals: A mediation analysis. Sustainability, 12, $1-12$.

[13] Schaufeli, W. B. (2012). Work engagement. What do we know and where do we go? Romanian Journal of Applied Psychology, 14(1), 3-10.

[14] Maslach, C., \& Leiter, M. P. (1997). The truth about burnout. San Francisco, CA: Jossey-Bass.

[15] Schaufeli, W. B., Salanova, M., Gonzalez-Roma, V., \& Bakker, A. B. (2002). The measurement of engagement and burnout. A confirmative analytic approach. Journal of Happiness Studies, 3, 71-92.

[16] Schauefeli, W. B. (2013). What is engagement? In C. Truss, K. Alfes, R. Delbridge, A. Shantz, \& E. Soane (Eds.), Employee Engagement in Theory and Practice. London: Routledge. 
[17] Memon, M. A., Salleh, R., Mirza, M. Z., Cheah, J. H., Ting, H., Ahmad, M. S., \& Tariq, A. (2020). Satisfaction matters: The relationships between HRM practices, work engagement and turnover intention. International Journal of Manpower.

[18] Hsieh, C. C., \& Wang, D. S. (2015). Does supervisor-perceived authentic leadership influence employee work engagement through employeeperceived authentic leadership and employee trust? International Journal of Human Resource Management, 26(18), 2329-2348.

[19] Cohen, J., Cohen, P., West, S. G., \& Aiken, L. S. (2003). Applied multiple regression/correlation analysis for the behavioural sciences $\left(3^{\text {rd }} \mathrm{ed}\right)$. Hillsdale, NJ: Erlbaum.

[20] Li, B., Li, Z., \& Wan, Q. Q. (2019). Effects of work practice environment, work engagement and work pressure on turnover intention among community health nurses: Mediated moderation model. Journal of Advanced Nursing, 75, 3485-3494.

[21] Lu, L., Lu, A. C. C., Gursoy, D., \& Neale, N. R. (2016). Work engagement, job satisfaction, and turnover intentions. A comparison between supervisors and line-level employees. International Journal of Contemporary Hospitality Management, 28(4), 737761.

[22] Agarwal, U. A., \& Gupta, V. (2018). Relationships between job characteristics, work engagement, conscientiousness and managers' turnover intentions. A moderated-mediation analysis. Personnel Review, 47(2), 353-377.

[23] Hermawan, I. P. D., Hartika, L. D., \& Simarmata, N. (2017). Hubungan work engagement dengan turnover intention: Studi pada karyawan PT. X. Jurnal Psikologi Mandala, 1(2), 16-22.

[24] Merissa, B. (2018). Pengaruh work engagement terhadap turnover intention melalui job satisfaction sebagai variabel mediasi pada PT. Lottle Shopping Indonesia Sidoarjo. Agora, 6(1).

[25] Plooy, J. D., \& Roodt, G. (2010). Work engagement, burnout and related constructs as predictors of turbover intentions. Journal of Industrial Psychology, 36(1), 1-13.

[26] Rachmatan, R., \& Kubatini, S. (2018). Relationship between work engagement and turnover intention among supermarket employee in Banda Aceh. Jurnal Psikogenesis, 6(1), 1-10.
[27] Baron, R. M., \& Kenny, D. A. (1986). The moderator-mediator variable distinction in social psychological research. Conceptual, strategic and statistical considerations. Journal of Personality and Social Psychology, 51, 1173-1182.

[28] Namazi, M., \& Namazi, N. R. (2016). Conceptual analysis of moderator and mediator variables in business research. Procedia Economics and Finance, $36,540-554$.

[29] Greenberg, J. (1987). A taxonomy of organizational justice theories. Academy of Management Review, 12, 9-22.

[30] Yean, T. F., \& Yusof, A. A. (2016). Organizational justice: A conceptual discussion. Procedia-Social and Behavioural Sciences, 219, 798-803.

[31] Colquitt, J. A. (2001). On the dimensionality of organizational justice: A construct validation of a measure. Journal of Applied Psychology, 86, 386-400.

[32] Cropanzano, R., \& Molina, A. (2015). Organizational justice. In J. D Wright (Eds.), International Encyclopedia of the Social \& Behavioural Sciences, Oxford: Elsevier.

[33] Cropanzano, R., \& Mitchell, M. S. (2005). Social exchange theory: An interdisciplinary review. Journal Management, 31, 874-900.

[34] Huang, Y. H., Lee, J., McFadden, A. C., Murphy, L. A., Robertson, M. M., Cheung, J. H., \& Zohar, D. (2016). Beyond safety outcomes: An investigation of the impact of safety climate on job satisfaction, employee engagement and turnover using social exchange theory as theoretical framework. Applied Ergonomics, 55, 248-257.

[35] Agarwal, U. A. (2014). Linking justice, trust and innovative work behaviour to work engagement. Personnel Review, 43(1), 41-73.

[36] Cao, T., Huang, X., Wang, L., Li, B., Dong, X., Lu, H., Wan, Q., \& Shang, S. (2020). Effects of organisational justice, work engagement and nurses' perception of care quality on turnover intention among newly licensed registered nurses: A structural equation modelling approach. Journal of Clinical Nursing, 29, 2626-2637.

[37] Navarro-Abal, Y., Gomez-Salgado, J., LopezLopez, M. J., \& Climent-Rodriguez, J. A. (2018). Organisational justice, burnout, and engagement in university students: A comparison between stressful aspects of labour and university organisation. 
International Journal of Environmental Research and Public Health, 15, 1-12.

[38] Abubakar, S., \& Kura, K. M. (2018). Organisational justice and turnover intention among frontline employees of electricity distribution companies in Nigeria. Retrieved from https://papers.ssrn.com/sol3/papers.cfm?abstract_id $=3471933$

[39] Ekmekcioglu, E. B., \& Aydogan, E. (2019). A moderated mediation model of the relationship between organizational justice and turnover intention. International Journal of Organizational Analysis, 27(4), 1073-1092.

[40] Mengstie, M. M. (2020). Perceived organizational justice and turnover intention among hospital healthcare workers. BMC Psychology, 8(19), 1-11.

[41] Suifan, T. S., Diab, H., \& Abdallah, A. B. (2017). Does organizational justice affect turnover-intention in a developing country? The mediating role of job satisfaction and organizational commitment. Journal of Management Development, 36(9), 1137-1148.

[42] Hur, W. M., Park, S., \& Moon, T. W. (2014). The moderating roles of organizational justice on the relationship between emotional exhaustion and organizational loyalty in airline services. Journal of Services Marketing, 28(3), 195-206.

[43] Kwantes, C. T., \& Bond, M. H. (2019). Organizational justice and autonomy as moderators of the relationship between social and organizational cynicism. Personality and Individual Differences, 151, $1-10$.

[44] Shahid, A., Nisar, Q. A., Azeem, M., Hameed, W. U., \& Hussain, S. (2018). Moderating role of organizational justice between emotional exhaustion and job-related outcomes. Pakistan Journal of Humanities and Social Sciences, 6(2), 205-220.

[45] Rath, J. (2011). Moderating role of justice perception in the relationships between stressors and strains (Master's thesis). San Jose State University, California.

[46] Wei, X., Hisrich, R. D., \& Peng, X. (2020). Chinese employees' psychological empowerment and voice behavior: Organizational justice as a moderator. Social Behaviour and Personality, 48(6), e8792.

[47] Memon, M. A., Salleh, R., Nordin, S. M., Hwa, C. J., Ting, H., \& Chuah, F. (2018). Person-organisation fit and turnover intention: The mediating role of work engagement. Journal of Management Development, 37(3), 1-14.

[48] Schaufeli, W. B. (2017). Applying the job demands-resources model: A 'how to' guide to measuring ans tackling work engagement and burnout. Organizational Dynamics, 46, 120-132. 